\title{
ENVIRONMENTAL MANAGEMENT ACCOUNTING IN THE MALAYSIAN MANUFACTURING SECTOR
}

\author{
JANICE ONG ${ }^{1, *}$ \\ RAMAN NOORDIN 1 \\ JUNAINAH JAIDI ${ }^{1}$
}

Received: 3 August 2019 / Revised: 31 December 2019 / Accepted: 26 January 2020

(C) 2020 Faculty of Business and Accountancy, University of Malaya. All rights reserved.

\begin{abstract}
A B S T R A C T
Research aim: This research investigates the relationship between EMA (monetary and physical) and environmental performance

Design/ Methodology/ Approach: This is a questionnaire-based survey study whereby the questionnaires are sent to 69 large manufacturing companies in Malaysia that are certified with ISO 14001 Environmental Management System.

Research finding: The study found no relationship between EMA (monetary and physical) and environmental performance.

Theoretical contribution/ Originality: The study highlights that the EMA literature is not yet comprehensive and as such, may result in the lack of a relationship with EMA.

Practitioner/ Policy implication: The results suggest that a formal environmental management accounting by the government may be able to assist to the lack of relationship between EMA and environmental performance.

Limitation/ Implication: The study sampled only large Malaysian manufacturing companies with ISO 14001 Environmental Management System. Additionally, a larger sample size may provide better results.
\end{abstract}

Type of article: Research paper

Keywords: Environmental Performance, Monetary Environmental Management Accounting, Physical Environmental Management Accounting, ISO 14001 Environmental Management System

JEL Classification: C30

\section{Introduction}

Environmental issues are a topic of concern globally. In Malaysia, commonly discussed environmental issues include the increasing carbon dioxide emissions, deforestation, excessive waste production and river pollution (Siew, 2018). At one point, Kuching was acknowledged as the most polluted city in the world based on the World's Air Pollution Quality Index (Mahadi, 2019). As such, natural resources have become very important and consequently incited debate on the lack of environmental improvements (Bakar, Abdullah, Ibrahim, \& Jali, 2017). As Malaysia is moving forward to an industrialised economy, it is difficult for the country to escape from environmental issues. Industrialisation in Malaysia has moved from material production to manufacturing (Bakar et al., 2017). This is apparent with Malaysia's GDP wherein the manufacturing sector contributes to

\footnotetext{
${ }^{1}$ Faculty of Business, Economics \& Accountancy, University Malaysia Sabah, 88400 Kota Kinabalu, Sabah, Malaysia

*E-mail for corresponding author: janiceong1993@gmail.com
} 
23 per cent of the GDP in 2017 (Department of Statistics Malaysia, 2017). In other words, the manufacturing sector in Malaysia has played a vital role and are primary contributors to Malaysian economic growth.

However, the problem with industrialisation is that it has detrimental effects on the natural environment due to the increasing pollution and wastes (Bakar, 2017). Even though the Malaysian manufacturing sector is important in supplying goods and services, it is also one of the key contributors to environmental issues (Mokthsim \& Salleh, 2014; Sakundarini \& Ghazala, 2018). The manufacturing sector not only affects the natural environment during the production process but also increases waste generation (Sakundarini \& Ghazala, 2018). In addition, carbon associated with a manufacturing company's process can disrupt the natural environment (Christine, Yadiati, Afiah, \& Fitrijanti, 2019). Unless addressed, these environmental issues will threaten the quality of life for future generations. In this regard, most studies explore the impact and measurement of environmental costs (Jasch, 2003).

Specifically, there is increased interest to quantify the environment as environmental costs are not considered significant in traditional management accounting (Burritt, 2004; Guenther, Endrikat, \& Guenther, 2016). As such, environmental management accounting (EMA) is a valuable means to overcome the weaknesses of traditional management accounting (Burritt, Hahn, \& Schaltegger, 2002; Faudah \& Arisman, 2013). According to IFAC (2005), EMA has no single or universally accepted definition. They suggest that EMA is the management of environmental and economic performance through the implementation of environmental-related accounting systems and practices. The UN Expert Working Group suggests that EMA is broadly defined as the identification, collection and thereafter the analysis and usage of physical information and monetary information for internal decision-making.

The literature has demonstrated the many benefits reaped from EMA such as superior cost-saving and sustaining competitive advantage (Jasch, 2003; Faudah \& Arisman, 2013; Jaidi, Noordin, Mail, \& Lim, 2018). Despite the importance and benefits of EMA, the adoption and implementation of EMA in many developing countries such as Malaysia is still weak (Jamil, Mohamed, Muhammad and Ali, 2015). Although EMA is important to improve a company's environmental performance, research of EMA in Malaysia is still relatively new and scant (Mokhtar, Jusoh, \& Zulkifli, 2016). In order to add to the scant literature and in view of the importance of the Malaysian manufacturing sector as previously mentioned, this paper assesses EMA in the Malaysian manufacturing sector. Thus, the current study looks into the relationship of environmental management accounting (monetary and physical) and environmental performance.

\section{Literature Review and Hypothesis Development}

\subsection{Environmental Management Accounting}

According to Jasch (2006), the US Environmental Protection Agency was the first formal agency to set up a formal programme in promoting the adoption of EMA in the early 90s. Since then, countries have begun to adopt EMA which was been recognised as an environmentally-related management practice. Much of the initiatives came from the United Nations Division for Sustainable Development. 
Later, the International Federation of Accountants (IFAC) decided to commission the development of a guidance document on EMA which was not a standard with defined requirements but provided a general framework to reduce international confusion (Jasch, 2006). According to IFAC (2005), EMA uses physical EMA and monetary EMA information for decision-making.

The literature generalises EMA as a technique used for the collection and analysis of the usage of financial and non-financial environmental information (Jasch, 2003). According to Frost and Wilmshurst (2000), a company exhibits EMA when it includes environmental information within the existing management system, standalone environmental accounting procedures, cost-benefit analysis, environmental audits and environmental reporting. Khalid, Lord and Dixon (2012) provided evidence of the existence of Frost and Wilmshurst's (2000) perspectives within environmentally sensitive companies in Malaysia.

On the other hand, Burritt et al. (2002) posit that monetary EMA and physical EMA are constructs in EMA. Monetary EMA refers to the monetary environmental information concerning environmental costs and earnings. In other words, it is the monetised value of the physical environment information (Khalid et al., 2012). For example, sales from wastes and tax incentives from energy-saving equipment. According to Jalaludin, Sulaiman, and Ahmad (2010), monetary EMA is an extension of the traditional management accounting method as it analyses and treats costs and revenues. In conclusion, monetary environmental management accounting tracks environmental-related costs through the financial flow.

Physical EMA is the physical environmental information and information related to the flow of energy, wastes, materials and water (Burritt et al., 2002). It is the physical units derived from environmental impacts, such as the amount of energy used. As such, it pays attention to the physical units like kilogram, tones or kilowatts. Through this, the strengths and weaknesses of the ecological surrounding the firm can be identified. According to Schaltegger, Hahn, and Burritt (2000), physical EMA is used primarily for the setting of goals and targets in order to monitor and control the environment. Thus, EMA can be used to determine day to day operations and strategies providing for better environmental information as the absence of proper measurement of environmental information hinders companies from generating relevant information for decision-making (Schaltegger et al., 2000; Burritt et al., 2003; Mokhtar et al., 2016).

\subsection{Resource-based View Theory}

The resource-based view theory grew from the industrial organisation view which suggested that a company's' success depends only on its external environment (Russo \& Fouts, 1997). The theory is introduced by Wernerfelt (1984) building around the internal competencies of a company and thus rooting competitive advantage from inside a firm. The resource-based view theory is applied to connect between the environment and the performance of a company. The theory rationalises that companies are heterogeneous in terms of resources and capabilities across companies (Branco \& Rodrigues, 2006). Thus, resources and capabilities are used to generate and employ the strategies of a company. 
Specifically, resources are the means through which companies accomplish company activities (Branco \& Rodrigues, 2006). Thus, they are the strength and weakness of a company and are known as the fundamental element where for a company to generate input into output. These include financial (tangible) and nonfinancial (intangible) assets (Wernerfelt, 1984). Some examples of resources consist of company capital, brand names, reputation, loyalty and more.

However, resources are not productive by their own and can only benefit when used by a company to perform its activities. According to Russo and Fouts (1997), a company has to consider its abilities to collect, integrate and administer to its bundle of resources. Thus, capabilities are the actions where resources are employed and companies engage in them to accomplish the company's objectives (Branco \& Rodrigues, 2006). In other words, capabilities provide a link between resources and permit their usage. They are the organisational process by which companies can expect organisational learning outcome by synthesising and acquiring knowledge, thus creating new usages and purposes from those resources and to achieve the desired objective.

On the other hand, the RBV theory highlights that, in order to create an opportunity for competitive advantage, there are four important facets to resources. They should be valuable, distinct and not easily (Hart, 1995; Hart \& Dowell, 2011). Hart and Dowell (2011) explained that there is value if customers are willing to pay or lower their cost, whereas distinct or rareness is the company's ability to command a premium and escape the competitive market. Lastly, inimitability is the company's resources that are not easily replicated by others. Conclusively, the significance of strategically placed resources and capabilities has been highlighted in that companies that better understand and nurture core abilities outperform companies that are still approaching strategic business planning the traditional way.

In view of the theory, the company's ability to produce resources is viewed as EMA. Specifically, the resources of a company may include environmental management, environmental systems, environmentally related information or environmental staffs (Jaidi et al., 2018). As these resources provide better environmental information to the company, more relevant information with regards to the environment may assists to provide better decision-making. Such decisions would then assist to contribute to cost reduction especially for the company's environmental-related activities (Ann, Zailani, \& Wahid, 2006). In turn, as the company possess better information, costs may be able to reduce, which will then be able to increase efficiency and productivity. Subsequently, the environmental performance of the company can be improved.

The environmental performance of companies is likely to become increasing as more environmental regulations and practices adhere to the industry. According to Phan and Baird (2015), the general gist of environmental performance is translated as the impact of the environmental activities of a company. To be specific, Ilinitch, Soderstorm and Thomas (1998) stress that environmental performance constitutes beyond financial disclosure of environmental liabilities. As such, they conceptualised four dimensions. Thus, environmental performance is the company's internal system, stakeholder relation, financial impact and internal compliance towards the environment. Sharma and Vredenburg (1998) 
and Christmann (2010) agree with the conceptualisation of a multi-dimension environmental performance.

Henri and Journeault (2010) provide empirical results on the use of environmental performance indicators which are similar to the aforementioned. Their result proposed that companies that are active with employing environmental strategy like environmental management tend to emphasis greater importance of environmental performance indicators. Likewise, Rodrigue, Magnan, and Boulianne (2013) asserted that the practice of a strategy that is able to lead to environmental performance requires beyond compliance with the existing legislation. Thus, companies must carry on developing capabilities and better foster resources to better attend to the existing environmental issues. Similarly, Solovida, and Latan (2017) link the use of environmental strategy to environmental performance and found favourable results. Specifically, Sharma (2000) posits that environmental strategy is the result of environmental actions that follow legislation as well as voluntary actions to reduce the impacts of the environment from company operations. According to the authors, an environmental strategy such as environmental management may assist in identifying the effect of environmental activities on environmental performance.

\subsection{Hypothesis Development}

In the literature, very little examinations look into the role of EMA as a driving force for environmental performance. The majority of the literature within EMA more often than not focused on environmental disclosure and cost measurement (Meiryani \& Susanto, 2019). Empirical research has provided insights into the relationship among influential factors and EMA and not so much on the environmental performance of companies (Le, Nguyen, \& Phan, 2019). As EMA highlights hidden environmental costs by revealing its source and location, such a strategy should bring about improvements in terms of environmental performance (Jasch, 2003). Burritt and Saka (2006) investigated the use of value chain based EMA, and with that, the inclusion of other integrated evaluation bases on its environmental impacts. The result is a steady decrease of environmental impacts resulting in high environmental performance.

Similarly, Jasch, Ayres, and Bernaudat (2010) found that both monetary EMA and physical EMA assist in improving industrial water management, pollution reduction and productivity. They applied the EMA assessment template provided by IFAC (2005). Despite the significance of EMA, the adoption and implementation of EMA are still relatively weak in a developing country like Malaysia (Jamil et al., 2015). Jalaludin et al. (2010) provided that EMA implementation is moderate, but their results produce positive correlations between EMA (monetary and physical) and environmental performance. A more recent study by Mokhtar, Jusoh, and Zulkifli (2016) found that EMA implementation is moderate, but which has shown an increase from previous studies. This could be an indicator that EMA is slowly but surely gaining more interest. Additionally, Jamil et al. (2015) provide that most companies have a specific budget for environmental activities but only practice physical environmental management accounting. They studied in the context of the Malaysian manufacturing sector. This is disheartening as the implementation of 
EMA should look into both physical and monetary EMA for better environmental performance. However, the study by Frost and Wilmshurst (2000) suggest that companies are already applying physical and monetary EMA but are not aware of the formal term.

In measuring EMA, many studies have applied Frost and Wilmshurst (2000) five perspectives for EMA implementation. The study by Khalid et al. (2012) in applying the five perspectives, strongly suggests that many companies' in Malaysia may not know that some form of EMA has already been implemented in the company but because of the lack of awareness of EMA, many companies in Malaysia cannot access the full benefits EMA can provide. On the other hand, Ramli and Ismail (2013) stated that relying solely on EMA is not sufficient enough to generate optimal benefits a company can produce.

Thus, EMA the application of IS0 14001 Environmental Management System (EMS) would assist companies as it is a way to prescribe frameworks and guidelines in implementing EMA. This is consistent with the results of Sirisom and Sonthiprasat (2011). Hence, this study will look into the Malaysian manufacturing companies that are certified with ISO 14001 EMS. Further, as Jamil et al. (2015) provided mixed results on the implementation of both physical EMA and monetary EMA as two separate constructs, it would be more comprehensive to warrant the two distinct EMA in this study in order to add to the increasing literature of EMA (Jalaludin et al., 2010). Additionally, Burritt et al. (2002) asserted that physical EMA and monetary EMA are two separate constructs, and more studies are needed. Thus, two hypotheses can be formed:

H1: There is a positive relationship between monetary EMA and environmental performance.

H2: There is a positive relationship between physical EMA and environmental performance.

\section{Methodology}

\subsection{Population and Sample}

A population is the entire group of people or something that a researcher wants to investigate (Sekaran \& Bougie, 2013). The manufacturing companies in Malaysia with ISO 14001 EMS are chosen as the population of this research due to its contribution to Malaysia's GDP. As of the year 2017, Malaysia's GDP grew from RM254.7 billion to RM265.8 billion (Economic Planning Unit, 2017). The manufacturing sector is the second largest contributor after the service sector (Department of Statistics, 2017). Additionally, the gross export by year in the manufacturing sector is increasing with the majority of the export in Malaysia belonging to the manufacturing sector. The sector consists of the following industries: (1) electrical and electronic products, (2) petroleum, chemical, rubber and plastic products, (3) non-metallic mineral, basic metal and fabricated metal products, (4) wood, furniture and paper products, (5) textile, wearing apparel and leather products, (6) food, beverage and tobacco products and (7) transport equipment and other manufacturing products.

The Malaysian economy is driven by the manufacturing sector which also indicates that business in the manufacturing sector will continue to rise. The 
increase in business also means that the sector will provide direct impacts to Malaysian's environmental health. Currently, the increase in pollution levels come from industrial wastewater, domestic and commercial activities. It is, therefore, apparent that the manufacturing sector is contributing to environmental damage. The Malaysian government recognises this and under the Economic Census (2016) whereby environmental protection expenditure was largely associated with the manufacturing sector.

For the purpose of this study, manufacturing companies in Malaysia are selected from the Federation of Malaysian Manufacturers Directory 2017. The directory can be divided into the small-medium enterprise and large manufacturing companies. For manufacturers, small-medium enterprise manufacturers are defined as companies with full-time employees not exceeding 200. In this study, large manufacturers that are certified with ISO 14001 Environmental Management System is chosen as the population of this research due to its abundance of resources and capabilities as compared with smallmedium enterprise manufacturers.

Companies implementing ISO 14001 standard are most likely to have better organisational resources and structure to more effectively executing environmental performance (Marshal \& Brown, 2003; Henri \& Journeault, 2008). The existence of such standard suggests that the company is committed to environmental impacts reductions. Thus, there is a greater likelihood that the company will establish environmental goals.

The random sampling method is applied based on the Federation of Malaysian Manufacturers Directory. A sample is the subset of a population (Sekaran \& Bougie, 2013). The sample size calculation is calculated using GPower 3.1 software (Banerjee, Chitnis, Jadhav, Bhawalker, \& Chaudhury, 2009). The software is typically for behavioural studies and is an excellent software that provides good precision power and the analysis of sample size (Cunningham \& McCrumGardner, 2007). The minimum sample size is calculated under the parameters $(E S=.15, \alpha=.05, \beta=.80)$ as proposed by Hair, Sarstedt, Hopkins, and Kuppelwieser (2014). As a result, the sample yielded 68 large manufacturing companies in Malaysia that are certified with ISO 14001 Environmental Management System.

\subsection{Operationalisation of Variables}

The study applied a questionnaire-based survey, and measurements from this study are applied based on the literature. Specifically, environmental performance items are adapted from Henri and Journeault (2010) using a five-point Likert scale. According to Henri and Hourneault (2010), the use of environmental impacts as a proxy for environmental performance limits the multidimensional concept of environmental performance to only one aspect. Therefore, environmental performance in this study consists of the dimensions of the internal system, stakeholder relation, financial impact and internal compliance. The internal system of a company is the improvements with regards to environmental issues into the operation of a company while stakeholder relation is the interaction with company shareholders, customers, government, local community and suppliers (Henri \& Journeault, 2010). On the other hand, the financial impact is the monetary consequences of a company's environmental activities and internal compliance is 
simply the company's compliance towards the minimum standard of the Malaysian laws and regulations (Henri \& Journeault, 2010).

To avoid common method biases, environmental management accounting (monetary and physical) items are adapted from Burritt et al. (2002) using a sevenpoint Likert scale. Common method biases pose a problem as measurement error may occur thus threatening the validity of the relationships between the measurements (Podsakoff, MacKenzie, Lee, \& Podsakoff, 2003). Common method biases are the variance that is caused by the measurement method rather than the constructs itself which should be represented through the measurements (Podsakoff et al., 2003). Thus, a much suitable way to avoid such instances is to include a scale that is unrelated to at least one other scale in the questionnaire (Lindell and Whitney, 2001).

According to Eutsler and Lang (2015), a fully labelled seven-point Likert scale is suggested to provide the greatest benefits. Their research is done in the accounting field which is applicable to this research endeavour. Hence, a sevenpoint Likert scale is applied to achieve better results. Accordingly, the monetary EMA is divided into the dimensions of past financial flow and future financial flow whereas physical EMA is divided into the dimensions of past material and energy flow as well as future material and energy flow. Additionally, a section of the survey is included to gather demographic data.

\subsection{Goodness of Measures}

To assess goodness of measures, two widely known analysis is performed, that is, factor analysis and reliability analysis (Sekaran \& Bougie, 2013). For factor analysis, the main purpose is to define the underlying structure among the variables (Hair et al., 2006). In particular, large observed items are reduced to a smaller number of factors but still retaining the nature and character of the original items. In particular, factors reflect the underlying process that has created the correlations among items (Tabachnick \& Fidell, 2013). In this study, principal component factors (PCA) with Varimax rotation is used to analyse all the variables. Varimax rotation is applied because it produces factor loadings that are either very high or very low, making interpretation easier (Tabachnick \& Fidell, 2013). On the other hand, Kaiser-Meyer Olkin (KMO) measures the sampling adequacy which determines if responses are adequate whereas Bartlett's test indicates the relationship among the items. Communality is the variance that is accounted for by a common factor in an observed set of items (Child, 2006).

This research applies the generally accepted assumptions by Hair et al. (2014) which are as follows: Kaiser-Meyer Olkin (KMO) values must exceed .05, Bartlett's test of sphericity is at least significant at .05, anti-image correlation of items is greater than .50 , communalities of items must be greater than .50 , factor loadings of greater than $.65(\alpha=.05, \beta=.80)$, factors with eigenvalues that are larger than one is considered significant, percentage of variance explained is $60 \%$ or higher, no cross-loaded (cross-loading occur if a variable has two or more factor loadings exceeding the factor loadings threshold).

To begin, environmental performance consists of 15 items before factoring. Two runs factor analysis is completed. All of the remaining 9 items have factor loadings of above the threshold required. The factors explain $78.68 \%$ of the 
construct. The final result is presented in Appendix A. Initially, monetary environmental management accounting is presented to be 14 items. Two runs factor analysis is completed. All of the resulting 12 items have factor loadings of above the threshold required. The factors explain 84.44 per cent of the construct. The final result is presented in Appendix B. Additionally, physical environmental management accounting is presented to be 11 items. Four runs of factor analysis are completed. As a result, the remaining 7 items have factor loadings of above the threshold required. The factors explain 79.09 per cent of the construct. The final result is presented in Appendix C.

Lastly, reliability analysis presents the stability and consistency of the items in measuring the concept (Sekaran \& Bougie, 2013). Cronbach's alpha ( $\alpha$ ) represents the reliability of the coefficient and indicates how well the items in a set of questionnaires are positively correlated to one another. Cronbach's alpha coefficient can range from .0 to 1.0. A Cronbach's alpha closer to 1 indicates higher internal consistency reliability. Sekaran (2003) suggest that .60 is the minimum acceptable coefficient. The results of the reliability analysis are summarised in Table 1.

Table 1. Reliability Analysis

\begin{tabular}{lcc}
\hline Variable & No. of Items & Cronbach's alpha $(\alpha)$ \\
\hline Environmental performance & 9 items & .702 \\
Monetary EMA & 12 items & .889 \\
Physical EMA & 7 items & .706 \\
\hline
\end{tabular}

Hence, it is concluded that the items reflect the variables applied in this study and the items are reliable. The final version is mailed to 337 large manufacturing companies with ISO 14001 Environmental Management Systems certificate. The list of the companies and the contact information of each company are obtained from the Federation of Manufacturers Malaysia 2017 Directory. The collected data are tested with Statistical Package for the Social Sciences (SPSS) software and structural equation modelling (SEM) with Partial Least Squares (PLS) using PLSSEM version 3.0.

\section{Empirical Analysis}

\subsection{Respondent's Profile}

The target population comprises 337 large manufacturing companies with ISO 14001 Environmental Management System certificate. Due to the small population, questionnaires are sent to the total target population where only 91 questionnaires were retuned. However, two of the questionnaires are partially completed, leaving 89 questionnaires. Thereafter, all responses are screened to check if data is correct, presence of missing values, outliers and normality of data. As a result, 20 responses are removed as they have extreme values. Finally, 69 questionnaires are usable and fulfil the minimum sample size calculation of 68 samples. The general rule to samples size should be larger than 30 and less than 500 for most research (Sekaran \& Bougie, 2013). According to Che Rohana (2007), a mail survey on emerging issues in Malaysia has shown a low but acceptable response. Studies in the same concept and population have provided a low 
response rate (Jamil et al., 2015; Jalaludin et al. 2016). Table 2 describes the profile of the respondents.

Table 2. Respondent's Profile

\begin{tabular}{llcc}
\hline Demographic Profile & Categories & Frequency & Percentage \\
\hline Main production & Electrical and electronic & 27 & 39.13 \\
activity & Engineering support & 4 & \\
& Petrochemical & 7 & 5.80 \\
& Food and sustainable resources & 1 & 10.14 \\
& Basic metal products and non-metallic & 18 & 26.09 \\
& mineral & & \\
& Machinery and equipment & 9 & 13.04 \\
& Wood & 3 & 4.35 \\
Company location & West Malaysia & 67 & 97.10 \\
& Sabah/Sarawak & 2 & 2.90 \\
Ownership status & Malaysian & 32 & 46.38 \\
& Non-Malaysian & 29 & 42.03 \\
& Joint ownership & 8 & 11.59 \\
\hline
\end{tabular}

\subsection{Measurement Model Testing}

The reflective measurement model postulates that there is a latent variable underlying a set of observed variables (Ramayah, Cheah, Chuah, Chuah, Ting, \& Memon, 2018). Thus, the measurement model assesses the item (indicators) loading on the theoretically defined latent variable. To begin, there are four assessments to this model, which is, internal consistency reliability, indicator reliability, convergent validity and discriminant validity. Firstly, all outer loadings are checked to meet the minimum required threshold value of .708 (Hair, Black, Babin, Anderson, \& Tatham, 2006). Several indicators produce low loadings and as such are deleted from the lowest loadings. These loadings are MEMA1, MEMA2, MEMA3 and EP5. According to Ramayah et al. (2018), low loadings can be kept when the minimum AVE result of .50 is achieved. Additionally, indicators cannot be deleted at more than 20 per cent of the total indicators in the model. Table 3 provides the result of the measurement model for the assessment of internal consistency, indicator reliability and convergent validity. To check internal consistency, composite reliability (CR) is taken into consideration. All constructs met the acceptable range of between 7 to .9. On the other hand, indicator reliability analyses whether a set of items is consistent with what it is supposed to measure. For indicator reliability, while not all loadings reach the threshold of .708, these indicators are maintained as CR (>.70) and AVE (>.50) values have reached. Additionally, convergent validity is the degree of a latent construct explaining the variance of its items (Hair et al., 2014). Convergent validity also suffices as AVE is greater than .50. On the other hand, to assess discriminant validity, the square root of AVE (diagonal) should be larger than the correlations (off-diagonal) of all constructs. Discriminant validity tests if the measurements are truly distinct from one another. The result is presented in Table 4 which provides adequate discriminant validity. 
Table 3. Internal Consistency, Indicator Reliability and Convergent Validity

\begin{tabular}{|c|c|c|c|c|}
\hline Construct & Items & Loadings & AVE & CR \\
\hline \multirow[t]{8}{*}{ Environmental Performance } & $\overline{\mathrm{EP} 2}$ & .715 & .512 & .893 \\
\hline & EP3 & .746 & & \\
\hline & EP4 & .644 & & \\
\hline & EP6 & .672 & & \\
\hline & EP7 & .802 & & \\
\hline & EP8 & .805 & & \\
\hline & EP9 & .618 & & \\
\hline & EP1 & .701 & & \\
\hline \multirow[t]{9}{*}{ Monetary EMA } & MEMA10 & .717 & .505 & .876 \\
\hline & MEMA11 & .720 & & \\
\hline & MEMA12 & .777 & & \\
\hline & MEMA4 & .574 & & \\
\hline & MEMA5 & .716 & & \\
\hline & MEMA6 & .659 & & \\
\hline & MEMA7 & .707 & & \\
\hline & MEMA8 & .790 & & \\
\hline & MEMA9 & .713 & & \\
\hline \multirow[t]{7}{*}{ Physical EMA } & PEMA1 & .765 & .548 & .894 \\
\hline & PEMA2 & .734 & & \\
\hline & PEMA3 & .767 & & \\
\hline & PEMA4 & .707 & & \\
\hline & PEMA5 & .759 & & \\
\hline & PEMA6 & .778 & & \\
\hline & PEMA7 & .662 & & \\
\hline
\end{tabular}

Table 4. Discriminant Validity

\begin{tabular}{lccc}
\hline & $\begin{array}{c}\text { Environmental } \\
\text { Performance }\end{array}$ & Monetary EMA & Physical EMA \\
\hline Environmental Performance & .716 & & \\
Monetary EMA & .426 & .711 & .740 \\
Physical EMA & .434 & .558 &. \\
\hline
\end{tabular}

\subsection{Structural Model Testing}

The second step to PLS-SEM is to assess the relationship between the latent constructs and hypothesis (Ramayah et al., 2018). Firstly, it is crucial to assess collinearity issues. Lateral collinearity occurs when there are two variables hypothesised to be casually related measure the same construct. Accordingly, all inner VIF values calculated through the assessment for the independent variables needed to be tested are less than the value of 3.3 indicating that lateral collinearity is not an issue in this study. In detail, monetary EMA produced the result of 1.644 whereas physical EMA produced 1.504. Thus, as the two values are less than 3.3, lateral collinearity is not an issue. This study also applies the guidelines by Hair et al. (2006) which measure the structural model in terms of path coefficients. In order to produce these values, a bootstrapping procedure with a resample of 5,000 was applied. Table 5 presents the results of path coefficient to test if the hypotheses are supported. This study adopts the thresholds set forth by Hair et al. (2006) wherein a p-value of less than .05 should indicate a t-value greater than 1.645 to 
support a hypothesis. Accordingly, the two hypotheses are not supported as the $\mathrm{p}$-value is more than .05 and $\mathrm{t}$-value is not greater than 1.645.

Table 5. Path Coefficient

\begin{tabular}{llccccl}
\hline Hypothesis & Relationship & $\begin{array}{c}\text { Std. } \\
\text { Beta }\end{array}$ & $\begin{array}{c}\text { Std. } \\
\text { Error }\end{array}$ & t-value & $p$-value & Decision \\
\hline H1 & Monetary EMA -> EP & .000 & -.006 & .000 & .500 & $\begin{array}{l}\text { Not } \\
\text { supported }\end{array}$ \\
H2 & Physical EMA -> EP & .137 & .111 & 1.225 & .110 & $\begin{array}{l}\text { Not } \\
\text { supported }\end{array}$ \\
\hline
\end{tabular}

\section{Conclusion}

The relationship between monetary environmental management accounting and physical environmental management accounting is first conceptualised from prior literature. Environmental management such as environmental management accounting improved the environmental performance of a company (Jasch, 2003; Burritt \& Saka, 2006; Jasch, Ayres, \& Bernaudat, 2010). Drawing from the resourcebased view theory, the resources and capabilities of a company, in this case, is recognised as environmental management accounting. Thereafter, companies are able to create superior value from the practice of environmental management accounting such as improvement in decision-making and cost reduction. It could also assist in improvements in efficiency and productivity. Such efficiency and productivity can then be translated as an improvement in a company's performance (Ramli \& Ismail, 2013). Hence, environmental management accounting is theorised to have a relationship with environmental performance. While other studies looked into environmental management accounting as a single construct, this study looked into environmental management accounting as two separate constructs, which is monetary environmental management accounting and physical management accounting. The rationalisation behind this is that companies in Malaysia may not be as progressive as other international countries in managing the environment and could still be traditionally evaluating only environmental costs.

However, the current study does not reflect the positive results from the literature. Much of the literature provided positive results that with the use of EMA can provide to better environmental performance (Burritt \& Saka, 2006; Jasch et al., 2010, Khalid et al., 2012). The recent study by Jaidi et al. (2018) provided supporting results for the relationship between EMA and environmental performance. However, while the study was performed in Malaysia, it analysed the hotel industry. The study by Christine, Yadiati, Afiah, \& Fitrijanti (2019) also provided that there is a positive relation between EMA and environmental performance, although the study was performed in other developing countries. According to Jalaludin et al. (2010), there is low adoption of monetary EMA and moderate adoption of physical EMA. This could indicate that manufacturing companies in Malaysia are perhaps still very much only managing the environment traditionally. In addition, it could mean that the comprehensiveness of environmental management accounting is still lacking in Malaysia.

According to Setthasakko (2010), the lack of a comprehensive environmental management accounting framework could very much likely lead to complications 
to successfully collect and evaluate environmental-related data. The lack of a formal environmental management accounting framework could also likely be a reason as companies have no formal reference on the application and the tools of environmental management accounting. For example, the Japanese government provides formal training and guidance for their companies in environmental management accounting. This suggests why this study produced no relationship between environmental management accounting and environmental performance within the Malaysian manufacturers. Formal training or a guidance book recognised by the Malaysian government may widen the awareness of EMA within the manufacturing sector. With encouragement from the government and possibly aligning companies towards EMA could lead to better overall environmental performance in Malaysia.

The findings of this study are not without its limitations. The small sample size of this study may vary with a larger sample size and may have yielded better results. This study also looked into large manufacturing companies that are certified with ISO 14001 Environmental Management Systems and ignored smallmedium manufacturers. On scrutinising the Federation of Manufacturers Malaysia Directory, there are smaller manufacturers that are certified ISO 14001 Environmental Management Systems, and as such, should not be ignored for future research. Additionally, while manufacturing companies in Malaysia play a significant role, other industry players should also be examined to improve the overall understanding of Malaysia's environmental performance.

Additionally, the literature suggests that other variables may influence environmental performance. For example, studies postulate that it is only through innovation (Wagner, 2008; Grekova, Bremmers, Trienekens, Kemp, \& Omta, 2013) or competitive advantage (Jaidi et al., 2018) that environmental performance can be improved. The mediating effect of innovation and competitive advantage towards the relationship between environmental management accounting and environmental performance could very likely provide better research outcomes. This could be supported with the natural resource-based view (NRBV) theory which is an extension or RBV theory. Nonetheless, the result of this study provided insights into the current literature in such a way that perhaps environmental management accounting is still not widespread in Malaysia and the studies in environmental management accounting should aim to be comprehensive. Notwithstanding, companies still need to prove their claim on being environmentally proactive as environmental implications continue to draw attention from around the world (Frondel, Horbach, \& Rennings, 2008; Sulaiman \& Mokhtar, 2012).

\section{References}

Ali, M.H., Zailani, S., Iranmanesh, M., \& Foroughi, B. (2019). Impacts of environmental factors on waste, energy, and resource management and sustainable performance. Sustainability, 11(8), 1-16. https://doi.org/10.3390/su11082443

Ann, G.E., Zailani, S., \& Wahid, N.A. (2006). A study on the impact of environmental management system (EMS) certification towards firms' performance in Malaysia. Management of Environmental Quality: An International Journal, 17, 73-93. https://doi.org/10.1108/14777830610639459 
Banerjee, A., Chitnis, U.B., Jadhav, S.L., Bhawalkar, J.S., \& Chaudhury, S. (2009). Hypothesis testing, type I and type II errors. Industrial Psychiatry Journal, 18(2), 127-131. https:// doi.org/10.4103/0972-6748.62274

Branco, M.C., \& Rodrigues, L.L. (2006). Corporate social responsibility and resource-based perspectives. Journal of Business Ethics, 69(2), 111-132. https://doi.org/10.1007/s10551-0069071-z

Burritt, R.L. (2004). Environmental management accounting: Roadblocks on the way to the green and pleasant land. Business Strategy and the Environment, 12(1), 13-32. https://doi.org/10.1002/bse.379

Burritt, R.L., \& Saka, C. (2006). Environmental management accounting applications and ecoefficiency: case studies from Japan. Journal of Cleaner Production, 14, 1262-1275. https://doi.org/10.1016/j.jclepro.2005.08.012

Burritt, R.L., Hahn, T., \& Schaltegger, S. (2002). Towards a comprehensive framework for ema link between business actors and ema tools. Australian Accounting Review, 12(27), 39-50. https:// doi.org/10.1111/j.1835-2561.2002.tb00202.x

Che Rohana, I. (2007). A Note on market Competition, Advanced manufacturing Technology and Management Accounting and Control System Change. International Review of Business Research Papers, 3(1), 301-320.

Child, D. (2006). The essentials of factor analysis. London: Continuum.

Chinander, K.R. (2001). Aligning Accountability and Awareness for Environmental Performance in Operations. In Proceedings of the Twelfth Annual Conference of the Production and Operations Management Society (pp. 1-8). https://doi.org/10.1111/j.1937-5956.2001.tb00375.x

Christine, D., Yadiati, W., Afiah, N.N., \& Fitrijanti, T. (2019). the Relationship of Environmental Management Accounting, Environmental Strategy and Managerial Commitment with Environmental Performance and Economic Performance. International Journal of Energy Economics and Policy, 9(5), 458-464. https://doi.org/10.32479/ijeep.8284

Christmann, P. (2010). Effects of "Best Practices" of Environmental Management on Cost Advantage: The Role of Complementary Assets. Management, 43(4), 663-680. http://dx.doi.org/10.2307/1556360

Claver, E., López, M. D., Molina, J.F., \& Tarí, J.J. (2007). Environmental management and firm performance: A case study. Journal of Environmental Management, 84, 606-619. https://doi.org/10.1016/j.jenvman.2006.09.012

Cunningham, J.B., \& McCrum-Gardner, E. (2007). Power, effect and sample size using GPower: practical issues for researchers and members of research ethics committees. Evidence Based Midwifery, 5(4), 132-136.

Department of Statistic Malaysia (DOSM). (2016). Press Release Population Projection (Revised), Malaysia, 2010-2040. Retrieved from https://www/dosm.gov.my/

Department of Statistic Malaysia (DOSM). (2017). Press Release Compendium of Environment Statistics. Retrieved from https://www/dosm.gov.my

Department of Statistic Malaysia (DOSM). (2017). Press Release Gross Domestic Product Third Quarter of 2017. Retrieved from https://www/dosm.gov.my/

Department of Statistic Malaysia (DOSM). (2018). Press Release Index of Industrial Production. Retrieved from https://www/dosm.gov.my/

Economic Planning Unit. (2017). The Malaysian Economy in Figure - 2017. Retrieved from https://www.epu.gov.my/

Eutsler, J., \& Lang, B. (2015). Rating scales in accounting research: The impact of scale points and labels. Behavioral Research in Accounting, 27(2), 35-51. https:// doi.org/10.2308/bria-51219

Frondel, M., Horbach, J., \& Rennings, K. (2008). What triggers environmental management and innovation? Empirical evidence for Germany. Ecological Economics, 66(1), 153-160. https://doi.org/10.1016/j.ecolecon.2007.08.016

Frost, G.R., \& Wilmshurst, T.D. (2000). The adoption of environment - related management accounting: an analysis of corporate environmental sensitivity. Accounting Forum, 24(4), 344365. https:// doi.org/10.1111/1467-6303.00045

Fuadah, L., \& Arisman, A. (2013). Adopting Environmental Management Accounting (EMA) in Indonesia. Forum Bisnis Dan Kewirausahaan Jurnal Ilmiah STIE MDP Hal -16, 3(1), 16-25. 
Fuzi, N.M., Habidin, N.F., Janudin, S.E., Yong, S., \& Ong, Y. (2016). Environmental Management Accounting Practices and Environmental Performance for Malaysian Manufacturing Industry. International Journal of Academic Research in Business and Social Sciences, 6(11), 22226990. http://dx.doi.org/10.6007/IJARBSS/v6-i11/2380

Grekova, K., Bremmers, H.J., Trienekens, J.H., Kemp, R.G.M., \& Omta, S.W.F. (2013). The mediating role of environmental innovation in the relationship between environmental management and firm performance in a multi-stakeholder environment. Journal on Chain and Network Science, 13(2), 119-137. https:// doi.org/10.3920/JCNS2013.1003

Guenther, E., Endrikat, J., \& Guenther, T.W. (2016). Environmental management control systems: a conceptualization and a review of the empirical evidence. Journal of Cleaner Production, 136, 147-171. https://doi.org/10.1016/j.jclepro.2016.02.043

Hair, J.F., Black, W.C., Babin, B.J., Anderson, R.E., \& Tatham, R.L. (2006). Multivariate data analysis. Upper Saddle River, NJ: Pearson Prentice Hall.

Hair, J.F., Sarstedt, M., Hopkins, L., \& Kuppelwieser, V.G. (2014). Partial least squares structural equation modeling (PLS-SEM) An emerging tool in business research. European Business Review, 26(2), 106-121. https:// doi.org/10.1108/EBR-10-2013-0128

Hart, S.L. (1995). A Natural-Resource-Based View of the Firm. The Academy of Management Review, 20(4), 986-1014. https:// doi.org/10.2307/258963

Hart, S.L., \& Dowell, G. (2011). A natural-resource-based view of the firm: Fifteen years after. Journal of Management, 37(5), 1464-1479. https:// doi.org/10.1177/0149206310390219

Henri, J.F., \& Journeault, M. (2010). Eco-control: The influence of management control systems on environmental and economic performance. Accounting, Organizations and Society, 35(1), https://doi.org/63-80. 10.1016/j.aos.2009.02.001

IFAC. (2005). International Guidance Document: Environmental Management Accounting.

Ilinitch, A.Y., Soderstrom, N.S., \& Thomas, T.E. (1998). Measuring corporate environmental performance. Journal of Accounting and Public Policy, 17(4-5), 383-408. https:// doi.org/10.1016/S0278-4254(98)10012-1

Jaidi, J., Noordin, R., Mail, R., \& Lim, T. S. (2018). Organisational Performance, Environmental Management Accounting Practices and Competitive Advantage: Evidence from Malaysia. International Journal of Applied Business and Economic Research, 16(4), 24-25.

Jalaludin, D., Sulaiman, M., \& Ahmad, N. N. N. (2010). Environmental management accounting: an empirical investigation of manufacturing companies in Malaysia. Journal of Asia-Pacific Centre for Environmental Accountability, 16(3), 31-45.

Jamil, C.Z.M., Mohamed, R., Muhammad, F., \& Ali, A. (2015). Environmental management accounting practices in small medium manufacturing firms. Procedia Social and Behavioral Sciences, 172, 619-626. https:// doi.org/10.1016/j.sbspro.2015.01.411

Jasch, C. (2003). The use of Environmental Management Accounting (EMA) for identifying environmental costs. Journal of Cleaner Production, 11, 667-676. https://doi.org/10.1016/S0959-6526(02)00107-5

Jasch, C. (2006). Environmental management accounting (EMA) as the next step in the evolution of management accounting. Journal of Cleaner Production, 14, 1190-1193. https:// doi.org/10.1016/j.jclepro.2005.08.006

Jasch, C., Ayres, D., \& Bernaudat, L. (2010). Environmental Management Accounting (EMA) Case Studies in Honduras - an Integrated UNIDO Project. Issues in Social and Environmental Accounting, 4(2), 89-103. https://doi.org/10.22164/isea.v4i2.48

Khalid, F. M., Lord, R., \& Dixon, K. (2012). Environmental Management Accounting Implementation in Environmentally Sensitive Industries in Malaysia. In $6^{\text {th }} \mathrm{NZ}$ Management Accounting Conference. Palmerston North.

Klassen, R.D. \& McLaughlin, C.P. (1996). The impact of environmental management of firm performance. Management Science, 42(8), 1199-1214.

Le, T.T., Nguyen, T.M.A., \& Phan, T.T.H. (2019). Environmental management accounting and performance efficiency in the Vietnamese construction material industry-a managerial implication for sustainable development. Sustainability, 11(19), 1-32. https://doi.org/10.3390/su11195152 
Lindell, M.K., \& Whitney, D.J. (2001). Accounting for common method variance in cross-sectional research designs. Journal of Applied Psychology, 86(1), 114-121. https:// doi.org/10.1037//0021-9010.86.1.114

Mahadi, A. (2019). Environment can threaten health, security. New Straits Times. Retrieved from https://www.nst.com.my/

Mokhtar, N., Jusoh, R., \& Zulkifli, N. (2016). Corporate characteristics and environmental management accounting (EMA) implementation: evidence from Malaysian public listed companies (PLCs). Journal of Cleaner Production Journal, 30, 1-12. https://doi.org/10.1016/j.jclepro.2016.01.085

Mokthsim, N., \& Salleh, K. O. (2014). Malaysia's Efforts toward Achieving a Sustainable Development: Issues, Challenges and Prospects. Procedia Social and Behavioral Sciences, 120, 299-307. https:// doi.org/10.1016/j.sbspro.2014.02.107

Pérez, A. E., Correa Ruiz, C., \& Carrasco Fenech, F. (2007). Environmental management systems as an embedding mechanism: a research note. Accounting, Auditing and Accountability Journal, 20(3), 403-422. https://doi.org/10.1108/09513570710748562

Phan, T.N., \& Baird, K. (2015). The comprehensiveness of environmental management systems: The influence of institutional pressures and the impact on environmental performance. Journal of Environmental Management, 160, 45-56. http://dx.doi.org/10.1016/j.jenvman.2015.06.006

Podsakoff, P.M., MacKenzie, S.B., Lee, J.Y., \& Podsakoff, N.P. (2003). Common Method Biases in Behavioral Research: A Critical Review of the Literature and Recommended Remedies. Journal of Applied Psychology, 88(5), 879-903. https:// doi.org/10.1037/0021-9010.88.5.879

Ramayah, T., Cheah, J., Chuah, F., Ting, H., \& Memon, M.A. (2018). Partial Least Squares Structural Equation Modelling (PLS-SEM) using SmartPLS 3.0. (2nd Ed.). Malaysia: Pearson.

Ramli, A., \& Sobre Ismail, M. (2013). Environmental Management Accounting Practices: A Survey of ISO 14001 Certified Malaysian Organizations. Journal of Energy Technologies and Policy, 3(11), 2224-3232. https:// doi.org/10.1016/j.sbspro.2014.06.043

Rodrigue, M., Magnan, M., \& Boulianne, E. (2013). Stakeholders' influence on environmental strategy and performance indicators: A managerial perspective. Management Accounting Research, 24(4), 301-316. https:// doi.org/301-316. 10.1016/j.mar.2013.06.004

Russo, M.V, \& Fouts, P.A. (1997). A Resource-Based Perspective on Corporate Environmental Performance and Profitability. The Academy of Management Journal, 40(3), 534-559. https:/ / doi.org/10.2307/257052

Sakundarini, N. \& Ghazila R. (2018). Malaysia's Pursuit of Sustainable Design. The Asia Dialogue. Retrieved from https:// theasiadialogue.com/

Schaltegger, S., Hahn, T., \& Burritt, R. (2000). Environmental management accounting: Overview and main approaches. Center for Sustainability Management (CSM).

Scott M.R., \& Brown, D. (2003). Corporate environmental reporting: what's in a metric? Business Strategy and the Environment, 12(2), 87-106. https://doi.org/10.1002/bse.354

Sekaran, U. (2003) Research Methods for Business: A Skill-Building Approach (4 ${ }^{\text {th }}$ Ed.). New York: Wiley.

Sekaran, U., \& Bougie, R. (2013). Research Methods for Business: A Skill-Building Approach (6 ${ }^{\text {th }}$ Ed.). New York: Wiley.

Setthasakko, W. (2010). Barriers to the development of environmental management accounting: An exploratory study of pulp and paper companies in Thailand. EuroMed Journal of Business, 5(3), 315-331. https://doi.org/10.1108/14502191011080836

Sharma, S., \& Vredenburg, H. (1998). Proactive corporate environmental strategy and the development of competitively valuable organizational capabilities. Strategic Management Journal, 19(8), 729-753. https://doi.org/10.1002/(SICI)1097-0266(199808)19:8\%3C729::AIDSMJ967\%3E3.0.CO;2-4

Sharma, S., 2000. Managerial interpretations and organizational context as predictors of corporate choice of environmental strategy. Academy of Management Journal, 43, 681-697. https://doi.org/10.2307/1556361

Siew, R. (2018). Environment must be in top ten. The Star Online. Retrieved from https://www.thestar.com.my/ 
Solovida, G.T., \& Latan, H. (2018). Linking Environmental Strategy to Environmental Performance: Mediation Role of Environmental Management Accounting. Sustainability Accounting, Management and Policy Journal, 8(5), 595-619. https://doi.org/10.1108/SAMPJ-082016-0046

Spencer, S.Y., Adams, C., \& Yapa, P.W.S. (2013). The mediating effects of the adoption of an environmental information system on top management's commitment and environmental performance. Sustainability Accounting, Management and Policy Journal, 4(1), 75-102. https:// doi.org/10.1108/SAMPJ-10-2011-0030

Sulaiman, M., \& Mokhtar, N. (2012). Ensuring sustainability: A preliminary study of environmental management accounting in Malaysia. International Journal of Business and Management Science, 5(2), 85-102.

Susanto, A., \& Meiryani. (2019). The impact of environmental accounting information system alignment on firm performance and environmental performance: a case of small and medium enterprises s of Indonesia. International Journal of Energy Economics and Policy, 9(2), 229-236. https://doi.org/10.32479/ijeep.7511

Tabachnick, B.G., \& Fidell, L. S. (2013). Using Multivariate Statistics (6th Ed.). Boston, MA: Pearson.

Wagner, M. (2008). Empirical influence of environmental management on innovation: Evidence $\begin{array}{llll}\text { from Europe. Ecological } & \text { Economics, }\end{array}$ https://doi.org/10.1016/j.ecolecon.2007.10.001

Wernerfelt, B. 1984. A resource-based view of the firm. Strategic Management Journal, 5(2), 171180. https:// doi.org/10.1002/smj.4250050207

World Bank. (2017). Malaysia's Economic Growth Accelerates to 5.8 Percent in 2017. Retrieved from http://www.worldbank.org/ 
Appendices

Appendix A. Factor Loadings for Environmental Performance

\begin{tabular}{|c|c|c|c|c|}
\hline \multirow[t]{2}{*}{ Items } & \multicolumn{4}{|c|}{ Factor Loadings } \\
\hline & F1 & F2 & F3 & F4 \\
\hline \multicolumn{5}{|l|}{ Emissions and discharges } \\
\hline Increase controls on emissions and discharges & .935 & .206 & -.089 & -.012 \\
\hline Increase filters on emissions and discharges & .855 & .282 & .139 & -.066 \\
\hline Improve employee morale & .828 & -.139 & .102 & -.192 \\
\hline \multicolumn{5}{|l|}{ Material costs and process efficiency } \\
\hline Reduction in material costs & .145 & .871 & .191 & -.004 \\
\hline Increased process efficiency & .048 & .827 & -.024 & .163 \\
\hline \multicolumn{5}{|l|}{ Operational management } \\
\hline Increase effective ways of managing operations & .156 & .197 & .741 & -.016 \\
\hline Increase residue recycling & .281 & .022 & .712 & .381 \\
\hline \multicolumn{5}{|l|}{ Internal compliance } \\
\hline Overall improved company reputation & -.057 & .076 & .042 & .938 \\
\hline Reduction in costs of regulatory compliance & -.222 & .239 & .149 & .829 \\
\hline \multicolumn{5}{|l|}{ Variance Explained (\%) } \\
\hline Total $=78.683$ & 22.981 & 21.396 & 17.703 & 16.603 \\
\hline Eigenvalues & 3.477 & 2.614 & 1.382 & 1.183 \\
\hline KMO & & & & \\
\hline Bartlett's Test Sig. & & & & \\
\hline
\end{tabular}

Appendix B. Factor Loadings for Monetary Environmental Management Accounting

\begin{tabular}{|c|c|c|c|c|}
\hline \multicolumn{5}{|l|}{ Future financial flow } \\
\hline Monetary environmental operational budgeting & .853 & .107 & .163 & .367 \\
\hline Relevant environmental costing & .782 & .234 & -.008 & -.194 \\
\hline Monetary environmental capital budgeting & .780 & .154 & .281 & .434 \\
\hline Environmental long-term financial planning & .770 & -.019 & .370 & .064 \\
\hline $\begin{array}{l}\text { Environmentally induced capital expenditure } \\
\text { Past financial flow }\end{array}$ & .664 & .528 & -.280 & .219 \\
\hline $\begin{array}{l}\text { Post assessment of relevant environmental } \\
\text { costing decisions }\end{array}$ & -.048 & .841 & .038 & .329 \\
\hline Environmental target costing & .296 & .808 & .422 & .002 \\
\hline \multicolumn{5}{|l|}{ Environmental lifecycle costing } \\
\hline \multicolumn{5}{|l|}{ Lifecycle budgeting and target pricing } \\
\hline Environmental lifecycle budgeting & .116 & .204 & .874 & .320 \\
\hline Environmental lifecycle target pricing & .179 & .242 & .856 & .231 \\
\hline \multicolumn{5}{|l|}{ Environmental projects and cost accounting } \\
\hline $\begin{array}{l}\text { Post investment of individual environmental } \\
\text { projects }\end{array}$ & .058 & .071 & .149 & .861 \\
\hline $\begin{array}{l}\text { Environmental costs accounting (for example, } \\
\text { variable costing, absorption costing, activity- } \\
\text { based costing) }\end{array}$ & .245 & .165 & .349 & .807 \\
\hline \multicolumn{5}{|l|}{ Variance Explained $(\%)$} \\
\hline Total $=84.443$ & 27.382 & 20.764 & 19.008 & 17.290 \\
\hline Eigenvalues & 5.687 & 1.812 & 1.541 & 1.093 \\
\hline $\mathrm{KMO}$ & & & & \\
\hline Bartlett's Test Sig. & & & & \\
\hline
\end{tabular}


Ong et al (2020) / Asian Journal of Accounting Perspectives, 13(1)

Appendix C. Factor Loadings for Physical Environmental Management Accounting

\begin{tabular}{|c|c|c|c|c|}
\hline \multirow[t]{2}{*}{ Items } & & \multicolumn{3}{|c|}{ Factor Loadings } \\
\hline & & F1 & F2 & F3 \\
\hline \multicolumn{5}{|l|}{ Past financial flow } \\
\hline Material flow assessment & & .884 & .165 & .022 \\
\hline Energy flow assessment & & .853 & -.222 & .110 \\
\hline Long-term physical environmental planning & & .699 & .506 & .237 \\
\hline \multicolumn{5}{|l|}{ Environmental impacts and budgeting } \\
\hline Relevant environmental impacts & & -.064 & .919 & -.056 \\
\hline Physical environmental budgeting & & .171 & .758 & .347 \\
\hline \multicolumn{5}{|l|}{ Lifecycle costing and inventories } \\
\hline Lifecycle costing & & .100 & .007 & .875 \\
\hline Lifecycle inventories & & .085 & .194 & .860 \\
\hline \multicolumn{5}{|l|}{ Variance Explained (\%) } \\
\hline Total $=79.086$ & & 29.280 & 25.567 & 24.239 \\
\hline Eigenvalues & & 2.781 & 1.523 & 1.231 \\
\hline $\mathrm{KMO}$ & 670 & & & \\
\hline Bartlett's Test Sig. & .000 & & & \\
\hline
\end{tabular}

